\title{
RELAÇÕES TRABALHISTAS E A REMUNERAÇÃO DO MAGISTÉRIO
}

(1931-1945)

\author{
Amália Dias \\ Universidade Federal Fluminense/CAPES \\ amaliadias@ig.com.br
}

\section{RESUMO:}

Examinamos a inserção do magistério particular do ensino secundário na categoria de "trabalhador", no contexto de reestruturação das relações trabalhistas e das funções atribuídas ao ensino secundário no país nas décadas de 1930 e 1940, o que implicou em mudanças importantes no estatuto profissional da categoria. Investigamos a elaboração de critérios para a definição da remuneração do magistério de ensino secundário particular. Sucessivas comissões, anteprojetos, pareceres, portarias e decretos focalizaram esta questão. A intervenção do Estado nas relações entre capital e trabalho caracterizou fortemente este processo, participando nas negociações e conflitos entre patrões e empregados.

Palavras-chave: Magistério; salário; legislação.

\section{WORKING RELATIONS AND TEACHING REMUNERATION} (1931-1945)

\begin{abstract}
:
The insertion of private secondary school teachers in the category of "worker" was examined in the context of restructuring the working relations and functions attributed to secondary education in the country in the 1930's and 1940's, which involved important changes in the professional statute of the category. We investigated the development of the criteria to define the teaching remuneration in private secondary education. Successive commissions, projects, proposals and decrees focused this question. The State intervention in the work and capital relation was principally characterized by this process, taking part in the negotiations and conflicts between employers and employees.
\end{abstract}

Keywords: Teaching, salary, legislation

Os estudos sobre a história da profissão docente destacam a importância da atuação do Estado no processo de profissionalização do magistério (NÓVOA, 1991). No Brasil, houve tentativas de transformar o estatuto profissional do magistério de ensino secundário ${ }^{1}$, com a implementação de políticas públicas em educação e trabalho pelo governo federal nas décadas de 1930 e 1940.

Trabalho e educação são dimensões marcantes da história daquele período, em que extensa legislação educacional e trabalhista foi desenvolvida para sustentar as bases do desenvolvimento econômico do país e do projeto político que liderava a construção do Estado, a partir do governo de Getúlio Vargas.

Assim é que uma vasta legislação foi implementada, voltada para o bem-estar social do "cidadão-trabalhador" e promover, preservar e ampliar a sua capacidade produtiva (GOMES,2005). A educação teria função essencial na construção desse novo 
cidadão brasileiro, que serviria à pátria na medida em que trabalhasse para o engrandecimento das riquezas nacionais:

O sistema educacional brasileiro deverá ter em vista, principalmente, a elevação do nível intelectual de todas as camadas sociais e o desenvolvimento do ensino técnico profissional, preparando o homem para o trabalho, modelando-lhe o caráter, dando-lhe consciência moral e tornando-o útil e capaz de atuar como fator eficiente do engrandecimento da nacionalidade (VARGAS, 1938).

Portanto, a educação foi um recurso indispensável ao êxito do projeto de Estado, tanto no que se refere à instrução do trabalhador, dotando-o de saberes úteis a sua atividade, mas também como meio de obter adesão ao regime, infundindo valores como o culto ao trabalho, à nacionalidade, à construção e preservação da nova ordem.

Naquele momento, os professores foram afetados, tanto por sua condição de educadores, quanto de trabalhadores, em face do projeto de setores do governo de engajar educação e trabalho como ingredientes essenciais ao desenvolvimento econômico e social do país. O Ministério da Educação e Saúde (MES) e o Ministério do Trabalho, Indústria e Comércio (MTIC) atuaram no estatuto profissional, nas condições de formação, de seleção, de carreira, de salário, além da própria atividade didática e pedagógica do magistério. Os trabalhadores do magistério foram tocados pela legislação trabalhista, pelos incentivos governamentais à sindicalização, pelas políticas de previdência e assistência social, pela criação da carteira profissional, assim como a regulamentação dos contratos de trabalho.

Importa observar que não era consenso na sociedade brasileira que o magistério fosse segmento da classe trabalhadora. O Sindicato dos Professores do Distrito Federal, criado em 1931, foi enquadrado, até 1938, entre os de profissões liberais, e as escolas não estavam classificadas nem como comércio ou indústria (COELHO, 1988, p.190). Antes mesmo de serem legalmente reconhecidos como tais, os professores procuraram, por meio dos órgãos do Ministério do Trabalho, o amparo da legislação trabalhista e social. Ou seja, os professores atuaram como trabalhadores, assumindo tal identidade e exigindo seus direitos, enquanto os donos de estabelecimentos de ensino manifestavam sua indignação, ao serem chamados para tratar de reivindicações de professores diante de Juntas de Conciliação. Nos anos de 1930, o Sindicato dos Estabelecimentos de Ensino, representante dos proprietários de escolas, foi um "intransigente opositor da aplicação às escolas da legislação social emergente" (Idem).

A questão da remuneração mobilizou, principalmente, o magistério de ensino particular posto que, comparando com a média salarial da categoria, pelo menos no Distrito Federal, a remuneração dos professores da rede particular era muito menor do que os da rede pública de ensino secundário (Idem, p.154).

É importante examinar a regulamentação da remuneração do professorado particular naquele contexto histórico de expansão dos estabelecimentos privados de ensino e de reordenamento dos postos de trabalho para o interior dessas instituições. A "remuneração adequada aos professores" constava na Reforma Francisco Campos (BRASIL,1931) como uma das exigências a serem observadas pelos estabelecimentos de ensino que se submetessem à inspeção federal, a fim de obter a equiparação ao Colégio Pedro II e expedir certificados oficialmente reconhecidos.

Devido a centralização político-administrativa que caracterizou o regime político no pós-1930, os debates e conflitos em torno do tema foram promovidos pelo Estado e mediados no interior da burocracia estatal. Através de comissões de estudos, relatórios, anteprojetos, substitutivos, pareceres e discursos, os Ministros do MES e do MTIC, patrões 
e empregados encaminharam suas propostas, manifestaram resistências, articularam alianças, interferindo nos rumos do processo decisório.

É sob essa perspectiva que a pesquisa da história da profissão docente nos anos de 1930 e 1940 precisa investigar as iniciativas do Estado no campo educacional e no campo da legislação social e trabalhista, a fim de notar as repercussões sobre a profissionalização da categoria. Neste período foram promulgadas quase todas as leis que passaram a regular as relações de trabalho no Brasil, sobre as condições de trabalho de menores e mulheres, os contratos de trabalho (jornadas, remuneração, férias), compensações sociais (previdência e assistência social) até a organização das instituições de enfrentamento dos conflitos de trabalho entre patrões e empregados (Comissões e Juntas de Conciliação, Comissões Coletivas de Trabalho).

Mas é necessário também considerar a autonomia relativa do Estado e situar a atuação dos docentes neste processo, o lugar que estes sujeitos ocupam nas relações sociais e do papel que eles jogam na manutenção da ordem social (NÓVOA, 1991).

A Reforma Francisco Campos criou para as escolas a obrigatoriedade de formalizarem, por escrito, contratos de trabalho com os professores (BRASIL, 1932). Tratava-se de definir normas para jornada de trabalho, férias, horas extras e salário. As mudanças ocorridas a partir da Reforma Francisco Campos favoreceram a diminuição do caráter liberal do magistério do ensino secundário, posto que o fim progressivo do regime de exames parcelados que caracterizava, até então, o curso secundário, implicou na queda da demanda por aulas particulares e a política de equiparação do ensino privado ao público fomentou a expansão da rede escolar de ensino, sobretudo particular, o que tornou os professores "mais dependentes de seus empregos" (COELHO, 1988, p.13).

Os professores se organizaram na forma sindical em consonância com a política social do Governo Provisório que instituiu a lei de sindicalização em 1931. Ricardo Coelho (1988) observa que a lei de sindicalização, embora delimitasse os contornos do movimento sindical e limitasse sua autonomia, oferecia em contrapartida o acesso ao Estado. Por esta brecha, os trabalhadores poderiam e de fato o fizeram, exigir a fiscalização de seus direitos e o atendimento de suas demandas salariais e trabalhistas, geralmente negadas pelo patronato, daí a importância de recorrer ao Ministério do Trabalho, às Juntas de Conciliação e Julgamento.

Segundo Ricardo Coelho (1988), os donos de estabelecimentos de ensino preferiram manter-se na órbita do Ministério da Educação, firmando contratos restritos ao período letivo com os professores, no lugar de assinar a carteira profissional e subordinarse à fiscalização do Ministério do Trabalho, Indústria e Comércio. Mas o Sindicato dos Professores do Distrito Federal, por exemplo, mobilizou-se pelo cumprimento, por parte dos empregadores, do decreto que instituiu a carteira profissional em 1932, exatamente porque aquele documento tinha validade perante o MTIC, posto que a regulamentação dos contratos implicava definições acerca da jornada de trabalho, férias e fixação de critérios para remuneração dos professores.

A definição de critérios para fixação da remuneração dos professores atravessou as décadas de 1930 e 1940. Sucessivas comissões, anteprojetos, pareceres, portarias e decretos focalizaram esta questão. A intervenção do Estado nas relações entre capital e trabalho caracterizou fortemente este processo, justamente num momento de expansão do ensino privado, ou seja, em contrapartida ao aval que o Estado forneceu à expansão do ensino privado mediante a política de equiparações, pela qual os estabelecimentos precisaram observar as exigências da inspeção estatal. 
"Remuneração condigna" e a habilitação profissional do magistério

Desde os anos de 1930, simultaneamente aos embates pela regulamentação dos contratos de trabalho, estava também em andamento a luta pela regulamentação da remuneração "adequada" prevista em lei. Em 1933, o coronel Agrícola Bethlem, expresidente do Sindicato dos Professores, propôs ao Conselho Nacional de Educação, enquanto chefe da Superintendência do Ensino Secundário do MES, a inclusão da fixação de uma remuneração mínima por aula de cinquenta minutos, no contrato de trabalho dos professores nas escolas privadas. Esta proposta foi rigidamente combatida no Conselho Nacional de Educação por meio de parecer enviado pelo padre Leonel Franca, representante de setores católicos e da iniciativa privada no ensino, sendo então recusada (Idem).

Nos resultados dos trabalhos da Assembleia Constituinte de 1934, a remuneração dos professores voltou a ser debatida, mas apenas vigorou, no texto final, a mudança do termo "adequada" - presente na Reforma Francisco Campos - para remuneração "condigna", termo que seria mantido pela Reforma Capanema de 1942 (BRASIL, 1942). Porém, na Carta de 1934, foram mais importantes do que a menção à "remuneração condigna" (Idem) os dispositivos que instituíram o salário mínimo, a jornada diária de oito horas, a indenização ao trabalhador dispensado sem justa causa, a igualdade entre trabalho manual e intelectual para fins de proteção social, e a Justiça do Trabalho, porque permitiu aos professores procurarem o amparo da legislação trabalhista sindical.

No Rio de Janeiro, enquanto o Sindicato dos Professores do Distrito Federal promovia campanha pela regulamentação dos contratos de trabalho, os donos de estabelecimentos de ensino consideravam como adequada a remuneração do professor, até mesmo "das mais bem remuneradas", empenhando-se na imprensa e junto aos poderes estatais para invalidar reclamações trabalhistas por parte dos professores. Os líderes patronais, como La-Fayette, julgavam os salários até desnecessários, posto que, "os produtos materiais poderão ser recompensados materialmente, ao passo que o trabalho intelectual e educativo não poderão ter como paga bens materiais" (1932, apud COELHO, 1988, p.150).

Os diretores dos estabelecimentos de ensino se concentraram na definição de uma remuneração mínima para os professores. Além de não reconhecer a insuficiência dos salários pagos, também eram contrários a uma elevação muito alta dos salários, alegando, como consequência, um aumento do custo do ensino. Ademais os donos de escolas consideravam importante manter as diferenças salariais entre os profissionais com maior tempo de trabalho no estabelecimento, importância da matéria e eficiência do professor (COELHO, 1988, p.153). Esses critérios informam como cada diretor ditava, de acordo com suas preferências, a remuneração dos professores, na ausência de regulamentação oficial.

Parte das reivindicações dos professores, organizados em associações e sindicatos, foi atendida pelo Decreto 2.028 de fevereiro de 1940, que estabeleceu a obrigatoriedade dos contratos de trabalho. Porém atribuiu competência ao Ministério da Educação para deliberar posteriormente sobre a fixação da "remuneração condigna" (BRASIL, 1940).

Meses após a publicação do decreto que instituía o registro profissional dos professores no Ministério do Trabalho, o Sindicato dos Professores do Distrito Federal encaminhou ao Presidente Getúlio Vargas um memorial no qual agradecia a sanção do decreto (SINDICATO DOS PROFESSORES DO DISTRITO FEDERAL, 1940a). Segundo o memorial, a significação da nova regulamentação sobre o trabalho do magistério inscrevia nos professores "um sentimento de respeito e gratidão [que] os impulsionará para a luta mais decidida em prol do aperfeiçoamento da nossa juventude". 
Após agradecimentos e compromissos declarados para com o Presidente, o memorial informava ao "Chefe da Nação" quais as questões "que exigem imediatas providências tendentes a coroar o sublime ato de V. Excia". Em seguida, os professores retomavam sua pauta de reivindicações, posto que o decreto postergou a solução sobre a remuneração da categoria.

Os professores exigiam a estabilidade após dois anos no emprego e alegavam que "os professores tornar-se-ão mais eficientes assim que seu trabalho, melhor remunerado, lhes permita dedicar mais tempo ao preparo pessoal. Professor mal pago, não pode ter estímulo, e, mais ainda, não poderá aperfeiçoar-se continuamente". Em face da importância da questão salarial para o magistério particular, o sindicato solicitava a conclusão dos estudos da Comissão instituída para contemplar o tema (Idem).

De fato, foi instalada uma comissão especial para deliberar sobre o assunto da remuneração, em abril de 1940, composta por Manoel B. Lourenço Filho (diretor do INEP), Francisco Montojos (diretor da Divisão do Ensino Industrial) e Oswaldo Gomes da Costa Miranda, técnico do Ministério do Trabalho (MINISTÉRIO DA EDUCAÇÃO E SAÚDE, 1940a).

O relatório da comissão (MINISTÉRIO DA EDUCAÇÃO E SAÚDE, 1940b), é uma fonte relevante para se conhecer como a remuneração, aspecto fundamental da profissionalização docente, foi elaborada naquele momento de organização das relações de trabalho no país em face do desenvolvimento do capitalismo industrial. Constitui material esclarecedor também para refletir sobre as relações entre a posição social e as condições econômicas do magistério naquele momento, posto que o trabalho da comissão sobre a remuneração discutiu a validade de contemplar o estado da qualificação dos docentes no Brasil e o significado social da função de ensinar como critérios para determinar a remuneração.

Nos trabalhos da Comissão, a relação entre remuneração e profissionalização emerge quando a comissão exige que, no tratamento da definição de critérios para o pagamento do professorado, "qualquer solução a ser aventada deveria colocar a questão da remuneração do professor na base da atividade profissional - atividade dos que se entreguem ao ensino como uma profissão, não só vivendo dele, mas vivendo nele e para ele" (Idem). A questão da remuneração é vista, também, como imbricada com o fomento ao aperfeiçoamento, à qualificação e habilitação profissional do magistério, com consequente elevação da qualidade do ensino.

Quanto à "complexa e delicada" tarefa proposta à comissão, de definir os critérios para remuneração do magistério dos estabelecimentos particulares de ensino, o relatório final diferenciava o conceito de "remuneração condigna", dos conceitos de "salário mínimo" e "salário profissional", em voga na legislação trabalhista do período. Sem expressão correspondente na legislação estrangeira, destacava-se "remuneração condigna" como um termo "peculiar" à legislação brasileira.

Os estudos da comissão especificaram como origem da expressão "remuneração condigna", o termo "remuneração adequada", presente no decreto de consolidação da reforma do ensino secundário de 1931, que estipulou as normas para inspeção dos estabelecimentos de ensino. Assim, como critério a ser averiguado na inspeção das escolas, a exigência da remuneração pretendia "resguardar de modo principal os interesses do ensino, e só indiretamente os interesses da classe" (Idem, p.3). Nesta passagem, a expressão "interesses do ensino" alude à inspeção como iniciativa do governo para garantir condições adequadas de funcionamento do ensino. Ademais, a remuneração deixou de ser apenas uma condição para inspeção e se estendeu como obrigatoriedade para todos os 
estabelecimentos particulares de ensino, sob pena de ser obstado o funcionamento do colégio ou ginásio.

O significado do termo "condigno" é apreciado pela comissão em duas acepções. Uma examina o termo como correspondente a ato ou obra: adequado, merecido, justo, devido, como proporcional ao merecimento ou valor. Numa segunda acepção, "condigno" refere-se a ato ou pessoa, digno, honrado, "em harmonia com a função social que exerce" ou ainda "relativo a prerrogativas, títulos ou privilégios".

Esta última acepção é que servirá - a princípio - de critério para o significado do termo "remuneração condigna" nos estudos da comissão. $\mathrm{O}$ argumento da comissão é de que, embora o termo "condigno" fosse condizente tanto com a atividade de ensinar - de "elevada significação social" - quanto com aqueles que exercem a função, para os efeitos da legislação trabalhista, o magistério deveria ser tratado como um entre outros gêneros de trabalho. Por isso, o termo "condigno" deveria ser relativo somente à qualificação profissional do professor, e não ao significado social da função de ensinar, embora fosse reconhecida sua importância.

Desta forma, houve que, embora "idealmente considerada, nenhuma função supera, em significação social, a do educador", a quem se entregava, pela formação da juventude, "os próprios destinos da nação", este critério "nada poderia significar para os efeitos de uma legislação de trabalho". (Idem, p.5).

A comissão mencionava exemplos de países em que a habilitação profissional determinava a remuneração dos professores, como era o caso da Inglaterra, França, Suécia, Irlanda, Escócia, Dinamarca. Apontava ainda os casos em que a remuneração do magistério era equiparada a de outras profissões de mesmo nível de formação, como médicos, juízes, agrônomos, procuradores da República, engenheiros etc., como ocorria na Polônia, Iugoslávia, Alemanha, Bulgária, Dinamarca, Hungria, Portugal e Holanda. Assim, a remuneração devia ser estabelecida conforme os títulos, formação e experiência dos professores. Ademais, justamente pelo elevado valor da "missão social" da função de ensinar, é que era do interesse do Estado a qualificação profissional do magistério "compatível com o alto destino do seu trabalho" (MINISTÉRIO DA EDUCAÇÃO E SAÚDE, 1940b, p.6).

No entanto, apesar do consenso sobre a pertinência de relacionar a remuneração à qualificação profissional, a comissão avaliava, com base em dados do Serviço de Estatísticas da Educação e Saúde, que este critério não seria adequado ao caso brasileiro, porque os níveis de qualificação do professorado não eram suficientes. Fazia poucos anos que havia sido instituída a obrigatoriedade de formação de professores do ensino secundário em instituição própria, daí a existência de poucos diplomados. Ademais, mesmo a formação de professores do ensino primário, que tinha lócus nas escolas normais existentes desde o século XIX, contrastava com o número de profissionais diplomados, "insuficiente para as necessidades reais do ensino" (Idem, p.8).

Cabe aqui uma reflexão sobre a defasagem entre o elevado prestígio social do magistério, consensual naquela sociedade, e a pouca incidência desta posição de classe quando se buscou definir políticas referentes ao estatuto econômico do professorado, à sua condição de classe. Para além da justificativa apresentada pela comissão, relegando o estatuto social da função de ensinar como aspecto a ser considerado na definição da remuneração do professor, devido às diretrizes da legislação trabalhista, cabe questionar em que medida se trata de uma distinção entre condição de classe e posição de classe.

$\mathrm{Na}$ definição do estatuto social do magistério, percebe-se que as características que definem a posição da classe social numa estrutura social não são apenas intrínsecas a ela, à sua condição de classe em face da situação econômica que ocupa nas relações de 
produção, mas suas propriedades de posição também resultam das suas relações com outras partes constituintes da estrutura (BOURDIEU, 1998).

Para a definição da situação econômica do professorado prevaleceram os interesses do empresariado do ensino privado, e nesta correlação de forças foi menor o peso funcional da posição de classe do magistério. Dialeticamente, a situação econômica incide sobre as margens possíveis de posição da classe na estrutura social (Idem), daí que o magistério tenha uma posição de classe que o identifica ao sacerdócio, ao apostolado, que são também funções com parcos rendimentos econômicos, mas de elevada significação social.

Após indicar a inadequação de se tomar a qualificação dos professores como critério para determinar a "remuneração condigna", o relatório passava a expor a pertinência de outros princípios a considerar no cálculo da remuneração.

Um estudo apresentado pelo Instituto Nacional de Estudos Pedagógicos sobre os vencimentos do magistério oficial em diversos países (Idem), baseou o argumento da comissão, de que havia muita diferença nas formas e valores de remuneração do magistério no país. Esta diferença era motivada não apenas pelo critério da qualificação, mas pelas condições socioeconômicas das diversas regiões.

Destaca-se, no relatório geral da comissão, a preocupação em considerar as condições de organização, manutenção e desenvolvimento do ensino particular no país e dos possíveis impactos da "remuneração condigna" sobre a receita dos estabelecimentos de ensino. O relatório defendia a compensação financeira à iniciativa privada neste setor, de forma que a remuneração condigna "não pode ser conceituada, portanto, com a exclusão de lucros da empresa, nem mesmo com participação direta dos professores nesses lucros" (Idem, p.11).

Os estudos da comissão atestavam que, mesmo sendo conhecida a existência de colégios particulares com "organização precária", "mal providos de mestres", e "não retribuindo o professorado como seria de desejar-se", era devido à importância da iniciativa privada na oferta de ensino, assim como da insuficiência de estabelecimentos de ensino público em todo o país, que a questão da remuneração do magistério não deveria prejudicar a obra do ensino particular de "extensão da educação ulterior à primária, obra de elevação da cultura média do país" (Idem, p.12).

Por isso, a comissão condenava o encarecimento das mensalidades e das contribuições dos responsáveis pelos alunos para a solução da questão da remuneração, alegando também que esta solução poderia levar à impossibilidade de famílias manterem seus filhos nas escolas, o que resultaria em evasão e prejuízo aos donos de estabelecimentos, assim como desemprego aos professores e redução do número de vagas de trabalho. Por fim, o aumento do valor das mensalidades e taxas do ensino concorreria para desestimular a iniciativa privada na criação e manutenção de escolas, o que também não satisfaria ao interesse público, "porquanto qualquer maior entrave à iniciativa privada na criação e manutenção de casas de ensino, significaria errônea orientação, em país, como o nosso, de fraca densidade cultural" (Idem, p.13).

Os argumentos da comissão conferem com a análise de Marlos Rocha (2000, p.118) sobre a política de ensino secundário dos anos 1930 e 1940, quando sustenta que houve uma "compatibilidade da forte interferência da União na regulamentação desse ensino com o privatismo escolar, bem como das relações privilegiadas que este estabeleceu com o Estado".

No resultado dos trabalhos da comissão, à expansão e manutenção do ensino, enquanto "interesse público", agregava-se também outro fator importante, pois a exigência de mais escolas deveria ser paralela à exigência de "melhores escolas". Sustentava-se que a 
elevação da qualidade do ensino dependeria da qualificação do professorado e "do aperfeiçoamento da capacidade do professor, em seu aspecto cultural e técnico, e da compreensão das responsabilidades morais e cívicas do magistério" (MINISTÉRIO DA EDUCAÇÃO E SAÚDE, 1940b, p.13).

Neste ponto, a comissão retomava a questão principal de seu estudo, defendendo que "a remuneração condigna é, sem dúvida, condição favorável a que se obtenham melhores professores" (Idem, p.14). Portanto a remuneração se constituía em um aspecto fundamental no processo de profissionalização do magistério e integrava um conjunto de ações do governo e de setores da sociedade civil que se empenhavam na profissionalização do magistério.

Os estudos consideravam que tanto a "remuneração condigna" quanto o estabelecimento do registro profissional no Ministério do Trabalho eram medidas que visavam a contribuir para o magistério "tornar-se atividade realmente "profissionalizada" (Idem, p.14), posto que, com exceção do ensino primário, “o magistério, na maioria dos casos, não representa a profissão principal, caracterizada por preparação ou aprendizagem específica, e atividade habitual e continuada, de que o indivíduo faça seu verdadeiro instrumento de subsistência" (Idem, p.14).

No tocante à remuneração, o relatório identificava claramente os sujeitos e os interesses envolvidos no processo. Longe de ter sido resolvida de forma autoritária, a definição dos critérios de remuneração envolveu a participação de representantes dos professores e de donos de estabelecimentos. Contudo, é válido dizer: nas formas permitidas pelo Estado e no interior da burocracia estatal, restringindo-se o processo decisório às instâncias superiores, pois era o poder executivo que deferia ou não as propostas de lei. Os indivíduos que tentaram influir nesse processo eram representantes de sujeitos coletivos organizados, ou seja, de órgãos da burocracia estatal, como membros do MES e MTIC, e, também, representantes da sociedade civil organizada, dos sindicatos de professores e de sindicatos de empregadores.

Pode-se apreciar, em parte, o processo que resultou no relatório apresentado pela comissão sobre a regulamentação da remuneração do magistério. Isto é importante porque desvela a concepção da legislação como palco de lutas sociais, de arranjos e conflitos entre relações de força, interesses, objetivos e concepções de mundo. Como evidenciam as postulações de Faria Filho, é importante conhecer o momento de produção dos dispositivos legais e "relacionar toda a prática legislativa e os produtos da mesma, as leis, com as relações sociais mais amplas nas quais elas estão inseridas e as quais elas contribuem para produzir" (FARIA FILHO, 2005, p.99). Afigura-se a definição de que o estudo da legislação deve ser realizado com base numa concepção precisa de Estado, a fim de se "verificar tudo aquilo de relacional e conflitivo que ele abriga, à sombra do tom aparentemente monocórdio da narrativa contida nos documentos" (MENDONÇA, 2005, p.13).Apontar este posicionamento metodológico no tratamento das fontes, da legislação, é da maior importância por suas estreitas relações com o posicionamento teórico assumido sobre o Estado (GRAMSCI,2007), que é uma contrapartida a concepções bastante recorrentes nas reflexões sobre o Estado no Brasil, nas quais o Estado é apresentado como um ente homogêneo, preciso, monolítico que paira, age violentamente e prevalece sobre a sociedade apática e fluida. Estes tipos de interpretação foram facilmente plasmados em análises sobre o Estado Novo, devido ao caráter golpista e autoritário do regime.

No decorrer dos trabalhos da comissão, diretores e professores de estabelecimentos particulares de ensino, ou seja, patrões e empregados, manifestaram-se junto à comissão por meio de memoriais, cartas, representações, telegramas e visitas. Ao fim das atividades, foram contabilizados 720 ofícios, 144 telegramas e 71 visitas recebidos. Sob a ótica da 
comissão, "por mais diverso que fosse o valor dessas contribuições" (MINISTÉRIO DA EDUCAÇÃO E SAÚDE, 1940b, p.15, grifo nosso) apresentavam alguns subsídios para estudo, somando 49 processos, de cerca de 300 páginas, relatados e discutidos, segundo consta.

A comissão empreendeu uma seleção deste material e, por essa seleção, é possível inferir a relação de forças na atuação de professores e donos de estabelecimentos influindo nos rumos dos trabalhos: de 49 processos, 30 foram arquivados por serem considerados de matéria alheia aos estudos da comissão "ou por insistirem em pontos de vista menos objetivos"; os 19 processos restantes, depois de relatados e discutidos, foram reservados para maior apreciação na fase final do trabalho.

É preciso saber que, destes 19 processos selecionados, 12 eram subscritos por diretores de estabelecimentos de ensino secundário e apenas quatro por associações de professores do ensino secundário, quais sejam: Sindicato dos Professores do Distrito Federal, Sindicato dos Professores de Campinas de São Paulo, União dos Professores do Ensino Secundário de São Paulo e os demais foram enviados pelo Sindicato dos Educadores Brasileiros do Distrito Federal, pelo técnico de educação Antonio Figueira de Almeida, e pelo professor José Pimentel Pinto. Fica, portanto, evidente a predominância da opinião da iniciativa privada junto à comissão.

Esta é uma informação preciosa, porque os significados das intenções e soluções prescritas nos dispositivos normativos devem ser entendidos a partir da correlação de forças, dos embates e consensos ocorridos "entre frações de classe distintas, em disputa pela inscrição de seus projetos junto às agências de Estado em sentido restrito" (MENDONÇA, 2005, p.12).

É essencial esclarecer "que quase na sua totalidade" (MINISTÉRIO DA EDUCAÇÃO E SAÚDE, 1940b, p.16) essas contribuições foram apresentadas por professores e diretores de estabelecimentos de ensino secundário, apesar da questão da "remuneração condigna" abarcar todo o magistério e níveis de ensino. Esta questão tornava-se mais importante para o ensino secundário devido à reorientação que se imprimiu a este ramo do ensino, desde a Reforma Francisco Campos, quando foi integrado ao regime escolar seriado, de frequência obrigatória. Esta mudança arrefeceu a procura por aulas particulares e cursos preparatórios, na medida em que a demanda acorreu aos estabelecimentos de ensino, o que reorientou a procura por empregos em ginásios e colégios.

O interesse dos empregadores na questão da remuneração também não era menor do que o do professorado. O "empresariamento do ensino privado" no pós-1930, motivado pela expansão da iniciativa privada, sobretudo do ensino secundário, implicou $\mathrm{o}$ surgimento de interesses empresariais no setor do ensino médio (ROCHA, 2000, p.141).

A predominância da opinião dos representantes dos donos de ginásios e colégios, verificada no relatório da comissão, inclusive os argumentos que pautaram a defesa de lucro dos empregadores, vai ao encontro da análise de Marlos Rocha sobre o processo de "cartorialização" do segmento empresarial do ensino, ou seja, houve o favorecimento estatal ao setor privado do ensino. Refere-se com esta expressão ao tipo das relações que se estabeleceram entre o governo e o ensino privado no período, com consequências importantes para o ensino secundário (idem).

Quanto aos demais níveis de ensino, a comissão informa que, para o ensino primário, "não são muitas as organizações de ensino desse grau, em que o professor apareça como empregado" (MINISTÉRIO DA EDUCAÇÃO E SAÚDE, 1940b, p.16). A incipiente organização de certos ramos do ensino profissional acarretava professores que trabalhavam individualmente ou em instituições semelhantes às do ensino secundário e, no 
caso do ensino superior particular, o magistério era geralmente exercido como "atividade meramente subsidiária" (Idem, p.16), tendo, então, o professor, outras fontes de renda. Essa comparação permite compreender que, naquele contexto, o professorado de ensino secundário era, no quadro geral do magistério, o setor mais interessado e dependente do emprego e do salário que recebia nas instituições de ensino particulares.

Em seus trabalhos, a comissão utilizou também um inquérito realizado em 1935, pela Diretoria Nacional de Educação, acerca dos salários do professores do ensino secundário no país, mas, além das queixas dos professores sobre seus salários e do risco de danos apontado pelos donos de colégios, de que o aumento de salários de professores poderia acarretar à iniciativa privada, concorrendo para diminuição da oferta do ensino, pouco se aproveitou do inquérito.

Em contrapartida, a comissão organizou novo inquérito, com a colaboração do Serviço de Estatística de Previdência e Trabalho do MTIC, divulgado junto aos donos de estabelecimentos e inspetores do ensino secundário, a fim de averiguar as condições econômicas das escolas no sentido de arcarem com a "remuneração condigna" dos docentes. Dos 1.507 questionários distribuídos, 1.336 foram devolvidos, o que demonstra a atenção dos donos de estabelecimentos à questão.

Enquanto o inquérito anterior, que tinha participação de professores, pouco serviu à comissão, o novo inquérito, levantado junto aos donos de estabelecimentos e inspetores do ensino, serviu de base para a definição dos critérios a serem considerados na definição de fórmulas para o cálculo da remuneração "condigna".

$\mathrm{O}$ tratamento dos dados do inquérito demonstrou à comissão três fatores que deveriam consubstanciar a solução da questão. As empresas de ensino tinham seus rendimentos potencializados ou minimizados em face da conjuntura econômica da região onde se localizavam, assim como a contribuição mensal dos alunos conforme a clientela dos estabelecimentos e a variação do efetivo de alunos. Assim, estes aspectos que influenciavam na arrecadação das escolas foram considerados para a definição dos salários (Idem, p.19).

O resultado dos trabalhos da comissão manteve as disposições existentes no Decreto n. 2.028 de 1940, ou seja, pagamento por aula; mês de 4,5 semanas; pagamento no período de exames e férias; pagamento de aulas excedentes; jornada diária de trabalho de no máximo seis aulas. Fixou uma fórmula para o cálculo da remuneração com base no salário mínimo, na contribuição mensal do alunado e no número de alunos por turma. A solução sugerida deveria ser aplicada ao magistério de ensino primário, secundário, normal e profissional, tendo sido feitas algumas alterações para a remuneração do professor de ensino particular superior, em face de exigências legais estabelecidas para sua qualificação e da menor jornada de trabalho exercida em comparação com os demais professores (Idem, p.24).

A fim de assegurar que não deixou de contemplar o significado de "condigna" que poderia referir-se ao mérito da atividade docente, a comissão sustentava que, ao tomar o preço pago pelos alunos aos estabelecimentos como vetor para os cálculos de remuneração docente, estava também contemplando o mérito profissional como critério para remuneração. Isto porque "decorre do mérito dos professores, especialmente, o renome e o valor do próprio colégio, e é esse mérito, que justifica, em grande parte o nível da contribuição a exigir dos alunos", de forma que a comissão buscou "na própria qualidade de trabalho do professor, o critério fundamental para a determinação de sua remuneração, que, a justo título, poderia receber assim o nome de 'remuneração condigna"'(Idem, p.21).

A análise dos trabalhos da comissão permite afirmar, porém, que foram definidos critérios de remuneração condigna aos lucros dos donos de estabelecimentos de ensino e 
não ao trabalho docente, visto que foram considerados itens que diziam respeito às condições econômicas dos estabelecimentos, sendo garantido o direito ao lucro, sem haver menção às condições econômicas dos professores empregados nestes ginásios e colégios.

Correlações de forças: Estado, capital e trabalho

Em face do desenvolvimento do capitalismo no Brasil, o trabalho produtivo não é somente criador de valores de uso, mas a utilização da força de trabalho precisa produzir a mais-valia para o capitalista. Os trabalhadores assalariados são expropriados do valor correspondente de sua força de trabalho, no momento que a dispõem ao empregador.

Com base na análise de Marx, explica-se a postura dos representantes dos empregadores, posto que, sob as relações capitalistas, "um mestre-escola é um trabalhador produtivo quando trabalha não só para desenvolver a mente das crianças, mas também para enriquecer o dono da escola. Que invista seu capital numa fábrica de ensinar, em vez de numa de fazer salsicha, em nada modifica a situação" (MARX, 2005, livro I, vol. 2, p.578).

Seguindo esta analogia de Marx entre o empresário do ensino e um empresário de qualquer outro ramo, emerge uma comparação entre o significado da "remuneração condigna", na forma como acabou sendo definida nas décadas de 1930 e 1940, e o significado do "salário mínimo".

Previsto na Constituição de 1934, o salário mínimo só foi instituído em 1936 e regulamentado dois anos depois, sendo a primeira tabela de salários expedida em 1940 (VIANNA,1978). Assim, durante os anos de 1930, os salários se fixaram por seu valor no mercado, fora da regulamentação do Estado. A fórmula adotada em 1940 manteve os padrões do salário mínimo "biológico" ou "vital", ou seja, o somatório das despesas diárias de um trabalhador adulto com alimentação, habitação, vestuário, higiene e transporte (idem, p.235).

A intervenção das agências estatais nas relações entre capital e trabalho, substituindo o mercado no estabelecimento dos preços de venda e compra da força de trabalho, se explica pela função que o Estado desempenhou no favorecimento da industrialização do país. O salário mínimo significou uma forma de acumulação de capital pelos empregadores, por meio da redução dos custos com a força de trabalho, ao mínimo que o trabalhador precisava para que pudesse reproduzir sua capacidade produtiva ao fim de uma jornada. Dessa forma, tomar o mínimo como parâmetro implicava aviltar o salário do trabalhador qualificado enquanto o mesmo salário se transformava num instrumento efetivo para acumulação industrial. Para os demais assalariados, traduzia-se numa melhora real das classes subalternas urbanas, que viviam em grande parte aquém do mínimo fixado em lei (Idem, ibidem).

$\mathrm{Na}$ fórmula que foi apresentada nos trabalhos da comissão, a "remuneração condigna" preservava a capacidade de lucro do empresariado do ensino. O Sindicato de Professores do Distrito Federal procurou demonstrar, em documento encaminhado ao Presidente Getúlio Vargas, que a solução apresentada pela Comissão implicava a diminuição do salário em vigor , e estabelecia um "salário mínimo", em vez da proclamada "remuneração condigna" (SINDICATO DOS PROFESSORES DO DISTRITO FEDERAL, 1940b). O ministro Gustavo Capanema submeteu o documento do Sindicato de Professores a Lourenço Filho, membro da comissão especial sobre remuneração (LOURENÇO FILHO, 1940a).

O Sindicato dos Diretores apoiou o encaminhamento dado pela comissão, de atribuir uma percentagem fixa sobre a mensalidade dos alunos, para o pagamento das aulas 
dadas. De fato, o mínimo de remuneração condigna prevista pela comissão era inferior aos salários já praticados numa grande maioria de colégios (COELHO, 1988, p.158).

Após aprovação do relatório da comissão especial pelo ministro Capanema, Lourenço Filho apresentou anteprojeto de portaria relativo ao assunto da remuneração dos professores (LOURENÇO FILHO, 1940b). O Sindicato de Professores do Distrito Federal voltou a expor os motivos da discordância com os resultados do trabalho da comissão sobre a remuneração (SINDICATO DOS PROFESSORES DO DISTRITO FEDERAL, 1940c), e Lourenço Filho (1940c) emitiu novo parecer, sugerindo ao ministro da Educação o arquivamento do documento encaminhado pelo Sindicato de Professores.

Assim, não foram atendidos os apelos feitos pelo Sindicato de Professores ao MES e ao Presidente Getúlio Vargas, para adiar a adoção das medidas propostas pela comissão especial, que foram fixadas na Portaria n. 8, de 16 de janeiro de 1941. Além de fixar data limite para o recebimento do salário, o que beneficiou a categoria, a partir daquela regulamentação, vários colégios puderam reduzir o que antes gastavam com pagamento de professores, embora não sem a reação contrária do Departamento Nacional do Ensino, que foi a público lembrar os diretores da expressa proibição de redução dos vencimentos, e também de professores que foram à Justiça do Trabalho denunciar colégios que estavam calculando indevidamente as remunerações, o que acarretava sempre prejuízo para os docentes (COELHO, 1988, p.159).

Em março de 1944, o Sindicato de Professores enviava ao MES um anteprojeto de lei, que tinha o apoio de todos os sindicatos de professores do país, para ser apreciado pela comissão que pretendia reformular a Portaria n. 8. Entre suas propostas, destaca-se a pretensão dos professores de assegurar a proibição da redução dos salários, do número de aulas e a alteração do horário sem seu consentimento. A proposta previa aumento por tempo de serviço num mesmo estabelecimento, como forma de premiar a dedicação do docente; pagamento por exame de prova parcial escrita ou por aluno, ou seja, uma gratificação por um trabalho que exigia esforço do professor e "fora de sua habitual ocupação" (Boletim do Sindicato dos Professores, 1944, apud COELHO, 1988, p. 161).

No tocante ao cálculo da "remuneração condigna", este se faria com base exclusiva no salário mínimo (Idem, p.160). Isto porque, para o Sindicato dos Professores, a fórmula prescrita na Portaria n. 8 ocasionou salários/aula diferenciados no mesmo segmento de ensino, devido às variáveis do número de alunos e das mensalidades de valores diferentes, conforme a série de ensino. A partir da nova proposta, a remuneração oscilaria apenas em função do segmento de ensino, sendo mais elevada nos cursos superiores e significaria aumento geral dos salários (Idem, p.161).

Em sua estratégia pelo estabelecimento de uma remuneração "condigna" de fato, o professorado articulou em todo o país uma homenagem ao Presidente Getúlio Vargas. Em 27 de junho de 1944, Getúlio Vargas recebeu um memorial na presença de 500 professores e representantes de sindicatos de todo o país que reivindicava a transformação, em decretolei, do anteprojeto que tramitava no MES sobre a remuneração dos professores, sendo observadas integralmente as propostas encaminhadas no anteprojeto do sindicato. Em setembro daquele ano, o mesmo sindicato cobrava o compromisso do Presidente, em telegrama com mais de 500 assinaturas, "para a imediata fixação do salário condigno dos professores" (Boletim do Sindicato dos Professores, 1945, apud COELHO, 1988, p.162).

Os donos de colégios resistiam às demandas dos professores, sobretudo naquele contexto em que a guerra impunha contenção de despesas; a Coordenação de Mobilização Econômica havia proibido, em abril de 1944, qualquer aumento na contribuição cobrada aos alunos. 
A reforma do ensino secundário de 1942, sob a gestão de Gustavo Capanema na pasta da Educação e Saúde, estabeleceu que as pessoas naturais e jurídicas de direito privado, que mantinham estabelecimentos de ensino secundário, deveriam ser consideradas como no desempenho de função de caráter público, devendo observar, em matéria educativa, os deveres e responsabilidades inerentes ao serviço público (ROCHA, 2000, p.142).

Estabeleceu ainda a modicidade do custo das mensalidades. Os estudos para regulamentação deste dispositivo começaram em 1943, gerando crítica por parte do empresariado do ensino. Em 1944, ocorreu o Primeiro Congresso Nacional dos Diretores de Estabelecimentos de Ensino Secundário e Comercial, no qual elaboraram suas reivindicações ao governo: isenção de impostos, taxas ou tributos federais, estaduais ou municipais que incidissem sobre os estabelecimentos de ensino de propriedade privada; plano nacional de crédito escolar. O patronato sugeriu, ainda, para solução da questão da modicidade dos preços do ensino, a criação de Fundo Nacional do Ensino Secundário, formado pelos rendimentos excedentes dos capitais investidos nos estabelecimentos de ensino (Idem).

No entanto, em fevereiro de 1945, o presidente do Sindicato de Professores do Distrito Federal informava que os salários em vigor eram os mesmos há dez anos (Idem, p.161-162). Naquele ano as mensalidades ainda estavam congeladas, e uma greve estudantil contra a cobrança de taxa para prestação de exames inviabilizou a pretensão de aumento de arrecadação dos estabelecimentos de ensino particular. A conjuntura desfavorável aos donos de escolas engajou o sindicato desta categoria numa campanha de alarde sobre a "crise" e o "alto custo" do ensino, enquanto os professores organizados nos seus sindicatos prosseguiam tentando negociar com o governo suas bandeiras de luta (COELHO, 1988, p.168).

Segundo Ricardo Coelho (1988), contestado pelas escolas secundárias particulares, o projeto sobre a remuneração arrastava-se no Ministério da Educação, tendo Gustavo Capanema recusado o parecer da comissão, qualificado de "notável", pelo Sindicato dos Professores. Após audiência com o ministro Gustavo Capanema, em setembro de 1944, na qual obteve promessa de breve solução sobre o assunto, o sindicato endereçou outro memorial ao MES, em janeiro de 1945, sugerindo os nomes de Abgar Renault e Segadas Vianna para compor uma nova comissão. Para Ricardo Coelho, a intenção era afastar Lourenço Filho da comissão, pois, na opinião do Sindicato dos Professores, ele era partidário dos donos de estabelecimento de ensino (Idem).

Em março de 1945, foram ambos os sindicatos convocados para discutir a questão da "remuneração condigna". Nesse contexto, foi baixada a Portaria n. 205, em 5 de abril de 1945. Como foram assimilados vários itens de seu contraprojeto, o Sindicato dos Professores considerou a nova regulamentação como avanço nas suas lutas, até porque, mesmo num momento de alta inflacionária, os professores conseguiriam ter aumento de $33 \%$ nos salários. Porém, o salário/aula continuava vinculado às mensalidades e ao número de alunos por turma, tendo sido recusados os adicionais por tempo de serviço, gratificações por correções de provas e a realização de exames.

Getúlio Vargas foi novamente homenageado pelo Sindicato dos Professores do Distrito Federal em outubro daquele ano, recebendo do presidente da entidade, Wladimir Villard, e de cerca de 100 professores, o diploma de sócio de honra do sindicato (COELHO, 1988, p.167).

Segundo os estudos de Ricardo Coelho, até 1946, as negociações entre empregadores e empregados, por meio dos sindicatos, eram praticamente inexistentes, dando-se apenas na mediação do governo. Luiz Werneck Vianna ressalta, como 
característica das relações de trabalho, naquele contexto histórico, o fato de que o empresariado não aceitava o fator trabalho como interlocutor numa mesa de negociações e protelava a ação da sociedade política neste sentido, desvencilhando-se do cumprimento da legislação trabalhista (VIANNA, 1978, p.207).

Com a expedição da Portaria n. 204, em 1945, determinando aumento de $25 \%$ para o magistério particular, e, como em função do congelamento dos preços, os estabelecimentos não poderiam repassar os custos com pagamento de professores às mensalidades, houve forte resistência do empresariado que buscou, junto ao governo, políticas de compensação, como a suspensão do pagamento das taxas de inspeção cobradas aos estabelecimentos e a permissão para cobrança de cota adicional às mensalidades (ROCHA, 2000, p.145-146).

As comissões instituídas pelo Ministério da Educação para estudar os problemas relativos ao custo do ensino privado acabaram por estabelecer políticas de favorecimento às escolas privadas, que fundamentam o que Marlos Rocha denomina de beneficiamento de tipo cartorial ao ensino privado.

Estas conquistas do empresariado do ensino não se explicam apenas como medida complementar à postura governamental de não investir na expansão do ensino público. Segundo Marlos Rocha (2000), a manutenção e a expansão do ensino privado dependiam de que o Estado mantivesse o respaldo legal, instituído em 1931, para a expedição de diplomas de valor oficial. Por isso, buscavam uma relação cartorial com o governo, ao invés de reconstruir a autonomia de organização do ensino perdida com a criação da inspeção federal aos estabelecimentos de ensino.

$\mathrm{O}$ atendimento, por parte do governo, às reivindicações do ensino privado, que dera demonstrações de organização no congresso ocorrido em 1944, não podia prescindir, em meio à crise política de fins de Estado Novo, do apoio reconhecido do empresariado do ensino, daí as concessões públicas de crédito e a suspensão de impostos. A Portaria n.204 foi um exemplo dessa correlação de forças e da mediação do governo nas negociações. Após atender em parte à reivindicação de aumento salarial dos professores e atender à greve estudantil contra a cobrança de uma taxa, revogando a cobrança, o governo expediu uma série de medidas favoráveis aos donos de escolas, como concessões públicas de crédito e a suspensão de impostos (COELHO, 1988, p. 170).

\section{Conclusão}

Interessante notar que as negociações e os conflitos em torno da remuneração atravessam os anos de 1930 e 1940. Mesmo na conjuntura centralizadora e autoritária do Estado Novo, os conflitos entre empregadores e professores não foram totalmente solucionados. Neste sentido, a compreensão do Estado enquanto relação social, composto pela participação de diversos grupos, interesses e visões de mundo (GRAMSCI, 2007), pode esclarecer como, mesmo sob o Estado Novo, não se logrou solução definitiva para um aspecto tão caro ao processo de profissionalização da atividade docente, como é o tema da remuneração.

Quando se tratou da regulamentação das condições de trabalho, registro e remuneração do magistério particular, destacaram-se as negociações e conflitos observados sob o entendimento de relações entre sujeitos coletivos organizados na sociedade civil, como os sindicatos de professores e empregadores, com setores da sociedade política, quais sejam o Ministério do Trabalho, o Ministério da Educação e o poder executivo.

E, desta feita, confirmam-se os apontamentos do papel desempenhado pelo Estado nas relações entre capital e trabalho, mas num sentido de beneficiar as classes empresariais 
e submeter a classe trabalhadora à legislação social e trabalhista, com fins de potencializar a exploração da força produtiva do país e da acumulação de excedentes proveniente do emprego desta força. O empresariado do ensino, assim como algumas análises apontam para o papel da burguesia industrial, aceitou a tutela do Estado nas relações entre capital e trabalho, mas resistiu à regulamentação e execução dos dispositivos da legislação trabalhista e social que se estruturou nos anos de 1930 e 1940 (VIANNA, 1978; FRENCH, 1995).

Por outro lado, todo o empenho de setores do governo, por mais que priorizassem os interesses do ensino privado, não calou as manifestações e demandas dos professores do ensino secundário particular, organizados em sindicatos, ainda que os sindicatos fossem regidos por um sistema que buscava controlar as manifestações da classe trabalhadora.

Sobre as relações entre o Estado e a classe trabalhadora naquele cenário, sobressaem duas tendências explicativas sobre a ação política da classe trabalhadora, conforme o balanço realizado por Marcelo Mattos (2002). Uma delas, calcada no conceito de "sindicalismo populista", busca valorizar as concepções e práticas do Partido Comunista Brasileiro e de suas lideranças na direção da ação sindical e de um afastamento entre lideranças sindicais e base operária. O principal expoente desta linha é Francisco Weffort (1973). Sob essa ótica, o sindicalismo do período foi definido como pouco combativo e atrelado ao Estado, capaz de impedir a expressão de rumos contestatórios pelo movimento operário (idem). É uma concepção que imuniza o Estado da ação da sociedade.

Em perspectiva de análise oposta, os estudos de Eulália Lobo (1976) e os trabalhos que surgiram na linha de pesquisa, por ela implantada na UFF, sobre o movimento operário, serviram para rever explicações a respeito do movimento operário carioca e antecipar perspectivas de análise que se desenvolveriam anos depois.

Posteriormente, os estudos de Luís Werneck Vianna (1978) e Ângela de Castro Gomes (2005) buscaram superar os modelos explicativos que, na análise das relações entre Estado e classes trabalhadoras no pós-1930, ora enfatizavam a ação impositiva e repressiva do Estado sobre os sindicatos, ora ponderavam estas relações como barganha efetuada pelos trabalhadores, que teriam aderido ao sindicalismo, nos moldes do governo, para usufruir da legislação social.

A Invenção do trabalhismo de Ângela de Castro Gomes (2005) rejeita implicitamente o conceito de populismo vigente na produção anterior. $O$ "pacto trabalhista" entre o Estado e a classe trabalhadora, analisado pela autora, procurava enfatizar a "relação entre atores desiguais", mas, afastando-se do binômio da supremacia do Estado sobre uma classe manipulada (MATTOS, 2002).

No entanto, Marcelo Mattos chama a atenção para os deslocamentos de desenvolvimentos posteriores, feitos por outros autores, da análise de Ângela de Castro Gomes. Autores como Jorge Ferreira (2001) e Daniel Araão Reis Filho (2001) recaem numa visão extremamente valorativa do trabalhismo, ao enfatizar apologeticamente a atuação da classe trabalhadora, parecendo esquecer a fórmula proposta de "pacto entre desiguais". Essas recentes perspectivas de análise parecem desconsiderar a resistência dos empregadores em efetivar legislação social do governo Vargas, o desrespeito sistemático à legislação trabalhista, e as distâncias entre as prescrições da lei e sua efetivação na prática social.

Nem tanto ao mar, nem tanto a terra, nota-se, na confrontação deste breve balanço historiográfico com as fontes de pesquisa, que mesmo que organizados sob o regime sindical tutelado e sob lideranças compromissadas com o governo, os sindicatos de professores souberam usar os canais de acesso e influência e as formas de jogo político instituídas no pós-1930. Por meio dessas brechas, fizeram suas reivindicações, e marcaram 
posições na correlação de forças que consubstanciaram as disputas sobre os rumos da profissionalização docente, ainda que não tenham conseguido a hegemonia desse processo, em face das relações cartoriais do Estado com os empregadores, da força política significativamente maior dos empregadores na configuração do Estado.

Dessa forma, ainda que a legislação social e trabalhista tenha sido concebida para permanecer "letra morta" e ainda que não tenha correspondido exatamente a uma conquista da classe trabalhadora, ela se tornou um referencial para lutar por direitos sonegados (FRENCH, 1995).

Sob uma "relação entre desiguais", na definição de questões imediatas à condição de classe do magistério, a correlação de forças tendeu a favorecer ao patronato. Os argumentos da relevada função social do magistério, consensuais naquela sociedade, não foram válidos para definir os critérios de remuneração da profissão docente. Porém, a luta dos docentes do ensino secundário, coletivamente organizados, foi imprescindível para a defesa de seus direitos enquanto trabalhadores.

\section{Referências}

BOURDIEU, Pierre. Condição de Classe e Posição de Classe. In: A Economia das Trocas Simbólicas, São Paulo, Editora Perspectiva, 1998.

BRASIL. Decreto n. 19.890, de 18 de abril de 1931. "Dispõe sobre a organização do Ensino Secundário". Coletânea de Legislação Federal. Disponível em: <www.senado.gov.br/sicon>. Acessado em: 10 out. 2007.

BRASIL. Decreto-lei n. 21.241, de 4 de abril de 1932."Última Lei do Ensino Secundário. Novos Programas organizados pelo Departamento Nacional do Ensino para admissão à $1^{\mathrm{a}}$ série do curso secundário. Consolida as disposições sobre a organização do ensino secundário e dá outras providências". Disponível em: 〈www.senado.gov.br/sicon>. Acessado em: 08 out. 2007.

BRASIL. Decreto-lei n. 2.028, de 22 de fevereiro de 1940. "Institui o Registro Profissional dos Professores e Auxiliares da Administração Escolar, Dispõe sobre as condições de trabalho dos empregados em estabelecimentos particulares de ensino e dá outras providências". Disponível em: 〈www.senado.gov.br/sicon>. Acessado em: 10 jul. 2007.

BRASIL. Decreto-lei no 4.244, de 09 de abril de 1942. "Lei Orgânica do Ensino Secundário". Disponível em: www.senado.gov.br/sicon. Acessado em: 10 jul. 2007.

COELHO, Ricardo B. Marques. O Sindicato dos Professores e os Estabelecimentos Particulares de Ensino no Rio De Janeiro 1931 - 1950. Dissertação em História, Universidade Federal Fluminense, Niterói, 1988.

GOMES, Ângela de Castro. A invenção do trabalhismo. 3 ed. Rio de Janeiro: FGV, 2005.

GRAMSCI, Antonio. Cadernos do Cárcere. Volume 3: Maquiavel. Notas sobre o Estado e a Política. Rio de Janeiro: Civilização Brasileira, 2007.

FARIA FILHO, Luciano. "Fazer história da educação com E. P. Thompson: trajetórias de um aprendizado". FARIA FILHO, Luciano (org.) Pensadores sociais e história da educação. Belo Horizonte, Autêntica, 2005. 
FERREIRA, Jorge ."O nome e a coisa: o populismo na política brasileira”. In FERREIRA, Jorge (org.). O populismo e sua história. Debate e crítica. Rio de Janeiro, Civilização Brasileira, 2001.

FRENCH, John D. O ABC dos operários. Conflitos e alianças de classe em São Paulo, 1900-1950. São Paulo, Hucitec/Pref. Mun. De São Caetano do Sul, 1995.

LOBO, Eulália L. História do Rio de Janeiro: do capital comercial ao capital industrial e financeiro. Rio de Janeiro, IBMEC, 1976, 2 vols.

LOURENÇO FILHO (a). Parecer de Lourenço Filho a Capanema sobre memorial enviado pelo Sindicato de Professores do Distrito Federal sobre remuneração, 10/12/1940: FGV, CPDOC. GC g 1937.07.13, r. 48, Pasta I.

LOURENÇO FILHO (b). Anteprojeto de Portaria sobre remuneração do magistério apresentado a Gustavo Capanema, 11/12/1940: FGV, CPDOC GC g 1937.07.13, r. 48, Pasta I.

LOURENÇO FILHO (c). Carta ao Ministro Gustavo Capanema, 31/12/1940: FGV, CPDOC. GC g 1937.07.13, r. 48, Pasta I.

MARX, Karl. O Capital. Crítica da Economia Política. Livro I. 20a ed. 2 vol. Rio de Janeiro: Civilização Brasileira, 2005.

MATTOS, Marcelo Badaró. "Os desafios da História do trabalho hoje - pensando a partir da produção do Rio de Janeiro". Jornadas de História do Trabalho.Participação no painel Os desafios da História do trabalho hoje. 2002. Disponível em:

<http://www.labhstc.ufsc.br/VI\%20jornada\%20trabalho/mesa\%20pelotas.doc.> Acessado em 31 jan 2008.

MENDONÇA, Sônia Regina de. (Org.). O Estado Brasileiro: Agências e Agentes. Niterói: EdUFF: Vício de Leitura, 2005.

MINISTÉRIO DA EDUCAÇÃO E SAÚdE (a). Portaria n. 56 do Ministério da Educação e Saúde. Institui Comissão estudar regulamentação do art. 9 do Decreto-lei 2.028 de 22/02/1940 sobre remuneração condigna do professor, 04/04/1940: FGV, CPDOC. GC g 1937.07.13, pasta I, r. 48.

MINISTÉRIO DA EDUCAÇÃO E SAÚDE (b). Relatório Geral da Comissão Especial para fixação dos critérios a serem adotados na determinação da remuneração condigna dos professores em estabelecimentos particulares do ensino, apresentado ao Ministro da Educação Gustavo Capanema, p.15, 30/08/1940. FGV, CPDOC. GC g 1937.07.13, r. 48, Pasta I, p.11

NÓVOA, António. "Para o estudo sócio-histórico da gênese e desenvolvimento da profissão docente." Teoria e Educação, n. 4, 1991.

REIS FILHO, Daniel Aarão. "O colapso do colapso do populismo ou a propósito de uma herança maldita”. In: FERREIRA, Jorge (org.). O populismo e sua história. Debate e crítica. Rio de Janeiro, Civilização Brasileira, 2001.

ROCHA, Marlos Bessa Mendes da. Educação Conformada, a política pública de educação no Brasil.1930-1945. Juiz de Fora: Ed. UFJF; Brasília: Mec/Inep/Comped, 2000.

SINDICATO DOS PROFESSORES DO DISTRITO FEDERAL (a). Memorial do Sindicato de Professores ao Presidente da República, [1940]: FGV, CPDOC. GC g 1937.07.13, pasta II, r. 48. 
SINDICATO DOS PROFESSORES DO DISTRITO FEDERAL (b). Documento enviado pelo Sindicato de Professores do Distrito Federal ao Presidente Getúlio Vargas,

26/09/1940: FGV, CPDOC. GC g 1937.07.13, r. 48, Pasta I.

SINDICATO DOS PROFESSORES DO DISTRITO FEDERAL(c). Documento enviado pelo Sindicato de Professores do Distrito Federal ao Ministro da Gustavo Capanema, 11/12/1940: FGV, CPDOC.GC g 1937.07.13, r. 48, Pasta I.

VARGAS, Getúlio. A Nova Política do Brasil. 2 v. Rio de Janeiro: José Olympio, 1938.

VIANNA, Luiz Werneck. Liberalismo e Sindicato no Brasil. Rio de Janeiro: Paz e Terra, 1978.

WEFFORT, Francisco. "Origens do sindicalismo populista no Brasil". In: Cadernos CEBRAP, nº 4. São Paulo, abril/jun 1973.

Notas:

\footnotetext{
${ }^{1}$ Em analogia com a organização atual do sistema escolar, o ensino secundário correspondia nos anos 1930 e 1940 ao que hoje conhecemos como terceiro e quarto ciclos do ensino fundamental e o ensino médio. Constituía, na década de 1940, um dos níveis do ensino médio, que abrigava os ramos do ensino normal, comercial, agrícola, industrial, e secundário.

Recebido em: $\quad$ 10/11/10

Aprovado em: $06 / 04 / 11$
} 